\title{
Síncope recurrente como forma de presentación de la amiloidosis cardíaca
}

\author{
Recurrent syncope as a form of presentation of cardiac amyloidosis
}

Gabriel Pérez Baztarrica, Flavio Salvaggio, Rafael Porcile.

Médico Especialista en Cardiología, Departamento de Cardiología y Fisiología, Hospital Universitario;Facultad de Medicina, Universidad Abierta Interamericana; Buenos Aires, Argentina.

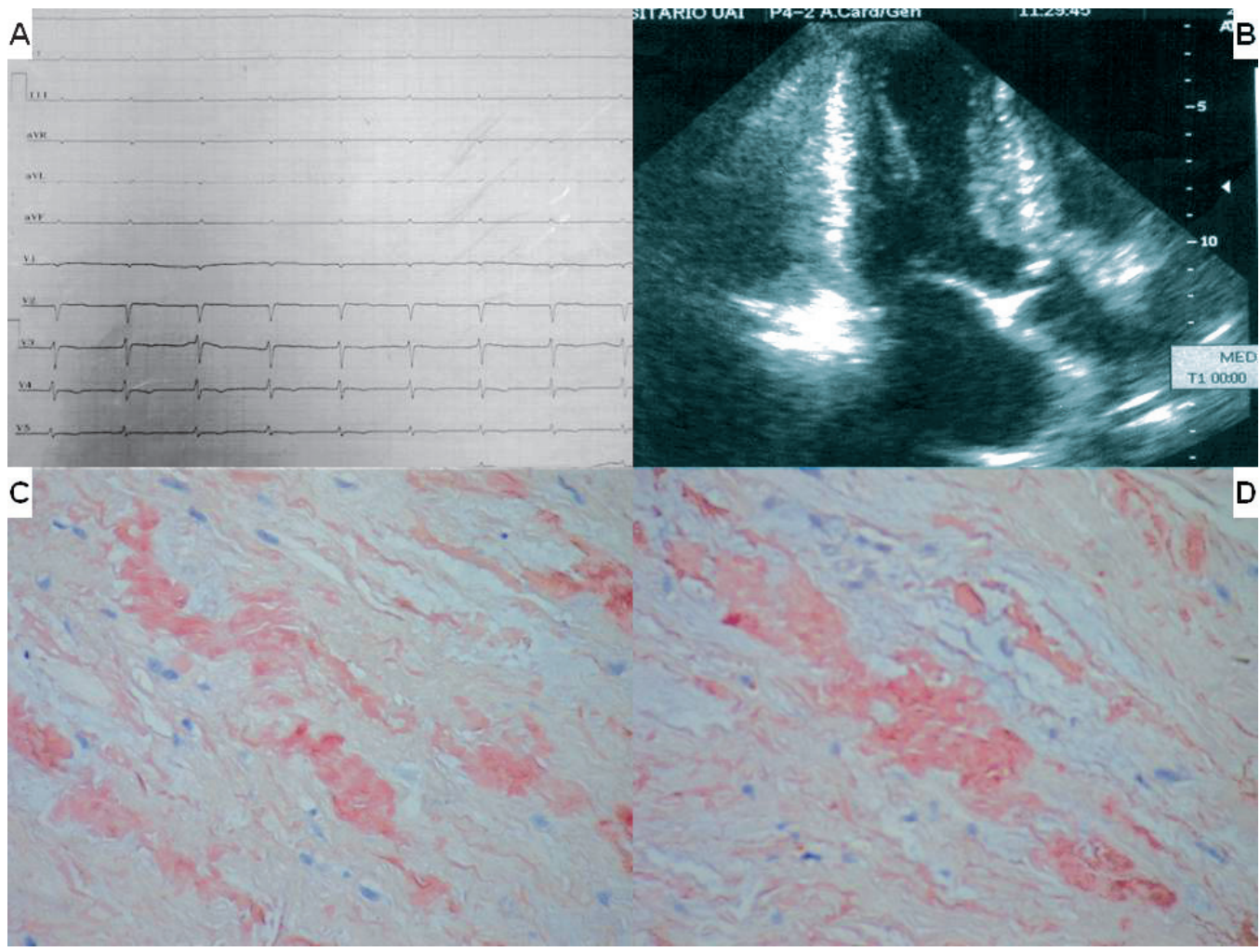

Se presentan imágenes correspondientes a paciente de 68 años con episodios reiterados de síncopes con pródromos (mareos y sudoración) en los seis meses anteriores. En la admisión, se detectó hipotensión ortostática sintomática. El electrocardiograma de 12 derivaciones mostró un bajo voltaje en derivaciones de extremidades (A). La ecocardiografía transtorácica (Esaote Mylab 40) mostró moderada hipertrofia ventricular izquierda con una apariencia granular (moteada) del miocardio compatible con infiltración miocárdica (B). Holter de 24 horas fue normal. La combinación de infiltración miocárdica con un bajo voltaje en el ECG apuntaba hacia una amiloidosis con implicación cardiaca. Biopsias de tejido extra cardíaco negativo. La biopsia endomiocárdica (BEM) es una técnica diagnóstica en pacientes con sospecha de miocardiopatía infiltrativas y que no se consigue demostración extracardíaca. Nuestro centro realiza BEM con tasas de complicaciones similares a lo publicado. En nuestro caso resultó positiva con la tinción de rojo Congo (C, D). La amiloidosis es una de las causas de hipotensión ortostática. Se recomendó al paciente mantener una correcta hidratación y técnicas posturales También se le administró fludrocortisona $0.2 \mathrm{mg}$ al día y se observó una mejoría en sus síntomas. Continúa en seguimiento por los servicios Cardiología y Hematología.

Recibido 4-3-2019; aceptado para publicación 29-3-2019

Dirección correspondencia a: Dr. Gabriel Pérez Baztarrica

Correo electrónico: gpbaztarrica@yahoo.com

Conflictos de interés. Los autores declaran no poseer conflictos de interés en relación a este artículo.

DOI: https://doi.org/10.5377/rmh.v87i1.11932 